\title{
KUMPULAN PUISI PERJAMUAN KHONG GUAN KARYA JOKO PINURBO SEBAGAI BAHAN AJAR BAHASA INDONESIA DI SMA (KAJIAN STILISTIKA)
}

\author{
Septian Refvinda Argiandini, Suyitno, Herman Joshep Walyo \\ Universitas Sebelas Maret \\ Email: septianrefvindaargiandini@student.uns.ac.id
}

\begin{abstract}
Abstrak: Kompleksnya unsur kebahasaan teks puisi seperti penggunaan diksi, gaya bahasa, dan citraan membuat guru dan siswa kesulitan memahami puisi. Minimnya bahan ajar sastra juga membuat pembelajaran sastra di sekolah kurang bervariatif. Penelitian ini bertujuan untuk mendeskripsikan dan menjelaskan (1) diksi Kumpulan Puisi Perjamuan Khong Guan, (2) gaya bahasa Kumpulan Puisi Perjamuan Khong Gua, (3) citraan Kumpulan Puisi Perjamuan Khong Guan (4) pemanfaatan diksi, gaya bahasa, citraan dalam pembelajaran bahasa Indonesia tingkat Sekolah Menengah Atas. Jenis penelitian ini adalah penelitian deskriptif kualitatif, menggunakan pendekatan stilistika sastra. Sumber data dalam penelitian adalah dokumen kumpulan puisi Perjamuan Khong Guan Karya Joko Pinurbo. Teknik pengambilan sampel menggunakan metode purposive sampling. Teknik pengumpulan data yang digunakan yaitu dengan cara analisis dokumen dan wawancara. Peneliti menggunakan triangulasi teori dan triangulasi sumber data sebagai uji validitas data. Teknik analisis data yang digunakan dalam penelitian adalah teknik analisis isi. Hasil penelitian ini dapat dikemukakan bahwa (1) diksi paling dominan dari kumpulan puisi Perjamuan Khong Guan Karya Joko Pinurbo adalah diksi konotatif. (2) Gaya bahasa yang paling dominan dari kumpulan puisi tersebut adalah gaya bahasa metafora. (3) Citraan yang paling dominan dari kumpulan puisi tersebut adalah citraan gerak. (4) Kumpulan Puisi Perjamuan Khong Guan dapat dimanfaatkan dalam pembelajaran teks puisi kelas X Sekolah Menengah Atas. Kesimpulan dari penelitian ini adalah bahwa hasil analisis diksi, gaya bahasa dan citraan dalam penelitian juga dapat dijadikan sebagai inspirasi untuk menulis puisi dengan nilai estetis yang tinggi.
\end{abstract}

Kata kunci: antologi puisi, kajian stilistika, bahan ajar.

\section{COLLECTION OF POETRY PERJAMUAN KHONG GUAN BY JOKO PINURBO AS TEACHING MATERIALS OF INDONESIAN LANGUAGE IN SENIOR HIGH SCHOOL (STILISTICS STUDY)}

\begin{abstract}
The complexity of the linguistic elements of the poetry text, such as the use of diction, language style, and imagery, makes it difficult for teachers and students to understand poetry. The lack of literature teaching materials also makes literature learning in schools less variedThis study aims to describe and explain (1) the diction of Kumpulan Puisi Perjamuan Khong Guan. (2) the language style of Kumpulan Puisi Perjamuan Khong Guan, (3) the imagery of Kumpulan Puisi Perjamuan Khong Guan. (4) the usage of diction, language style, and imagery of Indonesian Language learning for Senior High School. This type of research is qualitative descriptive using the stylistic approach of literature. The source of data in this study is the document of Kumpulan Puisi Perjamuan Khong Guan by Joko Pinurbo. The sampling techniques used the purposive sampling method. The data collection techniques applied were document analysis and interviews. Researchers also employed triangulation theory and data sources as a data validity test. The data analysis
\end{abstract}

BASASTRA Jurnal Bahasa, Sastra, dan Pengajarannya

Volume 9 Nomor 2, Oktober 2021, P-ISSN 2302-6405, E-ISSN 2714-9765 
technique used in the research is content analysis technique The results of the study are (1) The most dominant diction of Kumpulan Puisi Perjamuan Khong Guan is connotative diction. (2) The dominant language style in poetry anthology is metaphor. (3) The most dominant image from the anthology poetry is motion images. (4) Kumpulan Puisi Perjamuan Khong Guan can be used in learning poetry text for class X Senior High School.

Keywords: poetry anthologies, stylistic studies, teaching material.

\section{PENDAHULUAN}

Pada saat ini pembelajaran sastra belum beranjak menuju kebaikan dan cenderung terpinggirkan. Pembelajaran sastra di sekolah kurang diminati peserta didik. Begitupun pada materi teks puisi yang terintegrasi, dalam kegiatan menyimak, membaca, berbicara dan menulis. Pembelajaran sastra seringkali mengalami kesulitan tentang bagaimana penyajian materi dan menyusun bahan ajar yang tepat (Sutejo, 2010:50). Kemampuan pemahaman berpuisi pada peserta didik dapat memberikan stimulus untuk berkarya dan berproses positif dalam kehidupan di keluarga, sekolah maupun di masyarakat (Wicaksono, 2019:233)

Puisi dalam dunia pendidikan dijadikan sebagai salah satu bahan pembelajaran yang diajarkan di sekolah khususnya di kelas X SMA. Mengacu pada Permendikbud No. 24 Tahun 2016 tentang Kompetensi Inti dan Kompetensi Dasar Pembelajaran Kurikulum 2013. Adapun Kompetensi Dasar (KD) yang harus dicapai oleh peserta didik yaitu pada KD 3.17 Menganalisis unsur pembangun puisi dan KD 4.17 Menulis puisi dengan memerhatikan unsur kebahasaan teks puisi. Unsur kebahasaan yang dimaksud salah satunya yaitu diksi, gaya bahasa dan citraan (Gasong, 2019). Kompleksnya unsur kebahasaan teks puisi seperti penggunaan diksi, gaya bahasa, dan citraan membuat guru dan siswa kesulitan memahami puisi. Minimnya bahan ajar sastra juga membuat pembelajaran sastra di sekolah kurang bervariatif.

Kemampuan menganalisis unsur kebahasaan puisi khususnya pada aspek gaya bahasa sangat penting. Dengan memahami gaya bahsa peserta didik dapat dengan mdah mengapresiasi puisi yang dibaca ataupun didengarnya. Kemampuan menganalisis gaya bahasa dengan tepat akan memudahkan peserta didik dalam menciptakan puisi hasil karyanya sendiri. Hal tersebut sejalan dengan hasil penelitian Umami \& Anto, (2020:24-26) mengenai gaya bahasa perbandingan dalam kumpulan puisi karangan siswa SMA. Penelitian tersebut menyimpulkan bahwa, dengan memahami gaya bahasa puisi dapat melatih siswa untuk mengetahui dan memaknai puisi sampai pada tahap menciptakan puisi secara kreatif dan mandiri.

Salah satu sastrawan yang banyak menggunakan permainan bahasa dalam puisi yaitu sastrawan 
Joko Pinurbo. Kumpulan puisi Perjamuan Khong Guan merupakan karya sastra terbaru dari Joko Pinurbo yang diterbitkan pada Januari 2020. Buku kumpulan puisi Perjamuan Khong Guan karya Joko Pinurbo dipilih sebagai objek kajian karena memiliki unsur estetika dan gaya bahasa yang segar, serta terdapat nilainilai keteladanan yang dapat diambil. Kumpulan banyak mengangkat tema tentang kehidupan keluarga, kritik sosial, politik, dan sentilan keimanan (ketuhanan). Menurut Mukhlis \& Mulyani (2018) puisi kritik sosial cocok untuk dijadikan bahan bacaan siswa SMA.

Penelitian terkait stilistika puisi juga pernah dilakukan oleh Faizun (2020) pada puisi Ada Tilgram Tiba Senja karangan W.S Renda. Penelitian tersebut membahas terkait penggunaan, diksi dan gaya bahasa. Pada penelitian tersebut memfokuskan pembahasan stilistika sastra. Tanpa dikaitkan dengan pembelajaran sastra di sekolah. Penelitian terkait kumpulan puisi Perjamuan Khong Guan juga pernah dilakukan oleh Markoda (2020) dengan pendekatan analisis wacana mengenai sisi humor puisi-puisi Joko Pinurbo. Pada penelitian tersebut ditemukan bahwa puisi-puisi Joko Pinurbo banyak memuat komedi yang membahas terkait tragedi yang terjadi di Indonesia.

Kebaruan dari penelitian ini terletak pada penggunaan pendekatan metodologi penelitian. Peneliti tertarik untuk mengkaji kumpulan puisi
Perjamuan Khong Guan karya Joko Pinurbo menggunakan kajian stilistika sastra. Sejauh penelitian ini dilakukan Kumpulan Puisi Perjamuan Khong Guan belum pernah diteliti menggunakan pendekatan stilistika sastra. Penelitian ini juga dikaitkan dengan bahan ajar Bahasa Indonesia di sekolah. Khususnya pada materi ajar kelas X SMA KD. 3.17 dan KD 4.17. Metodelogi penelitian, pendekatan penelitian serta hasil penelitian yang dikaitkan dengan pembelajaran sastra di sekolah menjadi kebaruan penelitian.

Melalui kajian stilistika kumpulan puisi Perjamuan Khong Guan karya Joko Pinurbo dapat dijadikan sebagai bahan materi ajar yang relevan dalam pembelajaran Bahasa Indonesia di SMA. Khususnya pada materi pembelajaran di kelas $\mathrm{X}$ kurikulum 2013 KD 3.17 dan 4.17. Mengacu pada hal tersebut penelitian ini berjudul: Kumpulan Puisi Perjamuan Khong Guan Karya Joko Pinurbo Sebagai Bahan Ajar Bahasa Indonesia di SMA (Kajian Stilistika)

\section{METODE}

Penelitian menggunakan metode deskriptif kualitatif dengan pendekatan stilistika sastra. Data yang digunakan dalam penelitian adalah kata dan kutipan dari kumpulan puisi Perjamuan Khong Guan Karya Joko Pinurbo yang sesuai dengan rumusan masalah. Sumber data yang digunakan dalam penelitian berupa dokumen dan informan. Dokumen berupa kumpulan 
puisi Perjamuan Khong Guan. Sedangkan informan adalah guru bahasa Indonesia kelas $\mathrm{X}$ SMA. Pengambilan sampel pada penelitian menggunakan teknik purposive sampling, yaitu mengambil sampel yang disesuaikan dengan tujuan penelitian (Satori \& Komariah: 2017). Berupa, diksi, gaya bahasa, dan citraan. Teknik pengumpulan data dengan cara analisis dokumen dan wawancara mendalam.

Analisis penelitian dilakukan dengan cara membaca kumpulan puisi secara berulang. Data yang telah terkumpul divalidasi dengan teknik uji triangulasi teori dan sumber. Triangulasi teori diperoleh dengan cara menggunakan beberapa teori analisis stilistika yang relevan dengan data penelitian sehingga ditemukan kesimpulan yang tepat (Nugrahani, 2014). Triangulasi sumber digunakan untuk mengecek keterkaitan hasil analisis dengan bahan ajar Bahasa Indonesia teks puisi kelas $\mathrm{X}$ dengan cara wawancara pada guru Bahasa Indonesia sebagai informan.

Teknik analisis data pada penelitian ini menggunakan teknik analisis isi dengan model analisis mengalir. Pada tahap analisis, peneliti menganalisis isi kumpulan puisi Perjamuan Khong Guan. Berupa penggunaan diksi, gaya bahasa, dan citraan. Sedangkan untuk teknik analisis mengalir terdiri atas: pengumpulan data berupa diksi, gaya bahasa, dan citraan dalam kumpulan puisi. Reduksi data, dengan memilah dan memilih data sesai dengan tujuan penelitian. Data kemudian disajikan dalam bentuk tabel. Tahap terakhir yaitu, penarikan kesimpulan. Kesimpulan disampaikan untuk menjawab rumusan masalah yang dirumuskan di awal penelitian.

\section{HASIL DAN PEMBAHASAN}

\section{Diksi Kumpulan Puisi Perjamuan Khong Guan}

Secara keseluruhan terdapat 6 jenis diksi dalam kumpulan Puisi Perjamuan Khong Guan. Diksi tersebut antara lain: diksi konkret, diksi konotatif, diksi bahasa asing, diksi bahasa daerah, diksi sapaan khas, dan diksi dengan objek realitas alam. Pada kumpulan puisi tersebut lebih dominan menggunakan diksi konotatif. Terdapat 28 diksi konotatif yang ditemukan. Diksi tersebut digunakan untuk memberikan kesan keindahan.

Tabel 4.1 Diski Kumpulan Puisi Perjamuan Khong Guan

\begin{tabular}{|c|c|c|c|c|c|c|c|c|c|}
\hline Diksi & $\begin{array}{l}\mathbf{P} \\
1\end{array}$ & $\begin{array}{l}\mathbf{P} \\
2\end{array}$ & $\begin{array}{l}\mathbf{P} \\
\mathbf{3}\end{array}$ & $\begin{array}{l}\mathbf{P} \\
4\end{array}$ & $\begin{array}{l}\mathbf{P} \\
5\end{array}$ & $\begin{array}{l}\mathbf{P} \\
6\end{array}$ & $\begin{array}{l}\mathbf{P} \\
7\end{array}$ & $\begin{array}{l}\mathbf{P} \\
8\end{array}$ & Total \\
\hline Konotatif & 3 & 3 & 3 & 6 & 4 & 4 & 4 & 1 & 28 \\
\hline Konkret & 2 & 1 & & 1 & 2 & 1 & 2 & 2 & 11 \\
\hline Daerah & 3 & & 1 & & & 1 & 2 & 1 & 8 \\
\hline $\begin{array}{l}\text { Sapaan } \\
\text { Khas }\end{array}$ & & & & 1 & 1 & & 1 & 2 & 5 \\
\hline Asing & & 1 & & & & & 1 & & 2 \\
\hline $\begin{array}{l}\text { Objek } \\
\text { Realitas } \\
\text { Alam }\end{array}$ & 1 & & & & 1 & & & & 2 \\
\hline \multicolumn{9}{|c|}{ Jumlah } & 56 \\
\hline
\end{tabular}

\section{Keterangan:}

P1: Puisi Satu P2: Puisi Dua P3: Puisi Empat P4: Puisi Empat P5: Puisi Lima 
P6: Puisi Enam P7: Puisi Jutuh P8: Puisi Delapan

Diksi Konkret

Rakyat ialah Sukri, kusir yang memberi kursi kepada penumpang bernama Sukri dengan imbalan jempol dan janji. (D10/P2)

Kata rakyat pada puisi tersebut mengacu pada penduduk suatu Negara. Kata rakyat pada puisi tersebut tidak memiliki interpretasi lain selain makna harfiahnya. Kata konkret pada sebuah puisi merupakan kata yang mengandung makna yang sebenarnya tanpa ada imbuhan makna yang lain (Al-Ma'ruf \& Nugrahani, 2017:131). Sehingga dapat dikatakan bahwa kata rakyat merupakan kata konkret yang memiliki makna sebenarnya.

\section{Diksi Konotatif \\ Rakyat ialah Sukri, kusir yang memberi kursi kepada penumpang bernama Sukri dengan imbalan jempol dan janji. (D11/D12)}

Kata kursi di atas merupakan kata konotatif. Kata kursi dalam puisi tersebut memiliki makna suatu wewenang atau jabatan dalam suatu pemerintahan. Sedangkan kata jempol dan janji memiliki makna suatu janjijanji para penjabat kepada masyarakat yang sering kali tidak pernah ditepati. Kata tersebut memiliki makan yang berbeda dengan makna sebenarnya. Kata jempol dan janji sering digunakan masyarakat untuk menggambarkan janji-janji manis yang sering diungkapkan para penjabat saat pemilihan umum yang sering kali tidak ditepati.

Sukir dan andongnya tetap hepi kling klong kling klong.(D14)

Penyair menggunakan kata asing untuk memberikan kesan estetik. Kata hepi tersebut merupakan bahas agaul atau slang (Nurhasanah, 2014: 15). Istilah kata hepi sebenarnya berasal dari bahasa Inggris yaitu happy. Makna kata hepi dalam puisi tersebut yaitu senang atau perasaan gembira. Tokoh Sukir dilukiskan tetap gembira dengan pekerjaannya

Diksi lainnya yang ada dalam kumpulan puisi Perjamuan Khong Guan yaitu 5 diksi sapaan khas. Diksi sapaan khas dalam kumpulan puisi ini digunakan untuk menyebut seseorang. Beragam diksi yang digunakan dalam kumpulan puisi Perjamuan Khong Guan memberikan kesan yang unik dan estetik. Diksi yang terakhir yaitu diksi dengan objek realitas alam. Pada kumpulan puisi tersebut diksi dengan objek realitas alam digunakan untuk memberikan makna tertentu yang akan disampaikan penyair lewat objek alam. Penggunaan diksi dalam puisi tersebut juga berfungsi untuk membangun nuansa sesuai konteksnya.

Hasil temuan tersebut relevan dengan hasil penelitian Ginting, dkk (2021) yang meneliti terkait penggunaan diksi dan makna puisi yang berjudul Di ranjang Surgawi. 
Hasil penelitian tersebut menyimpulkan bahwa diksi dalam sebuah karya sastra puisi berperan untuk membentuk suasana dan penyampaian makna dari penyair untuk pembacanya. Perbedaan dari hasil penelitian tersebut yaitu dalam penelitian Ginting diksi yang temukan dalam penelitian tersebut banyak mengacu pada objek yang dituju secara langsung. Diksi-diksi yang dipakai hanya memiliki makna yang sebenarnya tanpa ada makna yang lain. Sedangkan dalam penelitian ini diksi konotatif lebih dominan dibandingkan diksi konkret. Sejalan dengan pernyataan tersebut Fransori (2017) menyatakan bahwa pemilihan diksi yang tepat dalam sebuah puisi dapat memberikan efek tersendiri bagi pembacanya.

Secara keseluruhan terdapat 56 diksi yang terkandung dalam kumpulan puisi Perjamuan Khong Guan. Keindahan dalam sebuah puisi hampir sebagian besar dipengaruhi oleh permainan bahasa dan diksi yang sesuai. Berbeda dari hasil penelitian Wilianti 2018 terkait analisis diksi puisi Karya M. Anwar M.H dengan judul Wajah Kita. Hasil penelitian tersebut menyimpulkan bahwa peranan diksi dalam puisi untuk menarik perhatian pembaca dengan kata-kata yang sederhana dan makna yang dalam. Pada kumpulan puisi Perjamuan Khong Guan menggunakan berbagai diksi yang memberikan kesan keindahan. Sejalan dengan hasil penelitian Djafar (2020) dalam analisi diksi dan gaya bahasa metafora, sebuah karya sastra puisi memiliki nilai estetik tinggi jika menggunakan beragam bahasa. Penggunaan diksi dalam kumpulan puisi Perjamuan Khong Guan juga berfungsi untuk memberikan efek ruang, waktu, nada dan amanat yang akan disampaikan oleh penyair.

\section{Gaya Bahasa Kumpulan Puisi Perjamuan Khong Guan}

Gaya bahasa dikenal sebagai retorika dengan istilah style yang memiliki arti cara penggunaan bahasa. Menurut Nurgiyantoro (2017:200) gaya bahasa merupakan penggayaan bahasa yang tidak memiliki makna harfiah dan maknanya cenderung tersirat. Pada sebuah puisi gaya bahasa digunakan untuk memperjelas makna dan maksud yang terkandung dalam larik-larik sebuah puisi (Mukhlis \& Mulyani, 2018) Pada kumpulan puisi Perjamuan Khong Guan, Joko Pinurbo menggunakan berbagai gaya bahasa dalam menyampaikan gagasannya. Gaya bahasa yang paling dominan yaitu gaya bahasa metafora. 
Tabel 2.1 Gaya Bahasa

Kumpulan Puisi

\begin{tabular}{|c|c|c|c|c|c|c|c|c|c|}
\hline Gaya & $\mathrm{P}$ & $\mathrm{P}$ & $\mathrm{P}$ & $\mathrm{P}$ & $\mathrm{P}$ & $\mathrm{P}$ & $\mathrm{P}$ & $\mathrm{P}$ & \multirow{2}{*}{ Total } \\
\hline Bahasa & 1 & 2 & 3 & 4 & 5 & 6 & 7 & 8 & \\
\hline Metafora & 1 & 2 & 1 & 1 & 3 & & & & 8 \\
\hline Personifikasi & & 1 & & 1 & & 3 & 1 & & 6 \\
\hline Onomotope & & 1 & & & & & & & 1 \\
\hline Koreksio & & & & 3 & & & & & 3 \\
\hline Simile & & & 1 & & & 1 & 1 & & 3 \\
\hline Paradoks & 1 & & & & 1 & 1 & & & 3 \\
\hline Sinisme & & & 1 & & & & & & 1 \\
\hline Hiperbola & & & & & & & 1 & & 1 \\
\hline Ironi & & & & & & & & 1 & 1 \\
\hline Anafora & 1 & & & & 1 & & & & 2 \\
\hline Simbolik & & 1 & & & & & & & 1 \\
\hline Eufeminisme & & & & & & & & 1 & 1 \\
\hline Retoris & 1 & & & & & & & & 1 \\
\hline & & JuI & IaI & & & & & & 32 \\
\hline
\end{tabular}

\section{Gaya Bahasa Metafora}

Rakyat ialah Sukri, kusir yang memberikan kursi kepada penumpang bernama Sukri dengan imbalan jempol dan janji. $(G 5 / G 6)$

Gaya bahasa metafora pada penggalan puisi tersebut dapat di tandai dengan penggunaan kata jempol dan janji. Kata imbalan jempol dan janji digunakan untuk membandingkan janji-janji palsu yang diberikan calon penjabat pada rakyatnya dengan gaya bahasa imbalan jempol dan janji. Gaya bahasa metafora juga digunakan untuk pada kata memberikan kursi untuk menggambarkan suatu posisi jabatan.

Sukri tak bisa duduk enak lagi, pantatnya sait digigit kursi (G7)

Gaya bahasa personifikasi pada penggalan puisi tersebut dapat dilihat dari larik pantatnya sakit digigit kursi. Penyair memberikan sifat manusia pada benda mati yaitu kursi. Kursi pada penggalan puisi tersebut dapat bertingkah laku seperti manusia.

Onomatope dan simbolik

Sukir dan andongnya tetap hepi, kling klong kling klong (G8)

Pada puisi tersebut penyair berupaya menirukan bunyi langkah kuda dan andongnya dengan kata kling klong kling long. Sehingga dapat dikatakan sebagai gaya bahasa onomatope. Penggalan puisi tersebut juga menggunakan gaya bahasa simbolik. Penyair dalam penggalan puisi tersebut menggunakan kata andong untuk menyimbolkan suatu pekerjaan yang dilakukan oleh rakyat. Andong yang merupakan suatu alat transportasi digunakan untuk meyimbolkan sebuah pekerjaan yang dilakukan masyarakat.

Tak ada yang bisa membangunkan

Nina yang sedang mabok bobok dalam pelukan negara agama (G15)

Pada larik tersebut terdapat kata mabok yang dicoret kemudian di sampingnya dituliskan pembenarannya dengan kata bobok. Gaya bahasa koreksio juga digunakan pada larik selanjutnya yaitu pada kata negara dikoreksi menjadi agama. Gaya bahasa ini digunakan untuk memberikan penegasan pada kata bobok dan agama. 
Gaya bahasa yang tepat dapat menggiring interpretasi pembaca kearah yang tepat sehingga dapat mendukung terciptanya nada dan suasana tertentu (Nurgiyantoro, 2017)

Berkerudung langit biru, Ibu yang hatinya kokoh membelah dan memotong-motong bulan . (G24)

Pada bait kedua puisi Perjamuan Khong Guan menggunakan gaya bahasa hiperbola. Ungkapan seperti berkerudung langit biru, membelah dan memotong-motong bulan termasuk sebagai ungkapan yang dilebih-lebihkan dan menjadi tidak masuk akal untuk ukuran nalar yang biasa. Gaya bahasa hiperbola pada sebuah karya sastra berperan sebagai pembentuk pengaruh puitis, lebih konkret, mudah dibayangkan dan karenanya dapat menimbulkan suatu keindahan (Nurgiyantoro, 2017:261). Penggunaan gaya bahasa hiperbola sangat dominan pada bait puisi tersebut. Semua larik-larik pada bait tersebut melebih-lebihkan dari suatu yang diekspresikan, yaitu tentang perjuangan seorang ibu dengan sepenuh tenaga dalam mengurus anakanaknya dan keluarganya.

Gaya bahasa dalam kumpulan puisi Perjamuan Khong Guan dimaksudkan untuk mengungkapkan sesuatu dengan cara yang tidak langsung atau menggunakan bahasa yang tidak menunjuk pada makna harfiahnya. Sejalan dengan teori dari Waluyo, (2010:55) bahwa penyair memanfaatkan gaya bahasa untuk menyampaikan makna secara tidak langsung. Gaya bahasa dalam kumpulan puisi Perjamuan Khong Guan digunakan untuk menghidupkan suasana, menambah kesan estetik serta mendorong kemampuan daya bayang atau imajinasi pembaca.

\section{Citraan Kumpulan Puisi Perjamuan Khong Guan}

Pada kumpulan puisi Perjamuan Khong Guan terdapat 4 citraan yang digunakan untuk membangkitkan imajinasi pembaca. Citraan gerak merupakan citraan yang banyak digunakan dalam kumpulan puisi Perjamuan Khong Guan. Terdapat 12 citraan gerak yang ditemukan dalam penelitian ini. Citraan gerak digunakan untuk membangkitkan daya imajinasi pembaca lewat pengalaman indra penglihatan dan pendengaran terhadap sesuatu yang bergerak. Citraan gerak menggambarkan gerakan pada umumnya atau sesuatu yang tidak bergerak menjadi seolah-olah menjadi bergerak (Wicaksono, 2019:128).

\section{Tabel 4.3 Citraan Kumpulan Puisi Perjamuan Khong Guan}

\begin{tabular}{lllllllllc}
\hline \multicolumn{1}{c}{ Citraan } & $\mathbf{P}$ & $\mathbf{P}$ & $\mathbf{P}$ & $\mathbf{P}$ & $\mathbf{P}$ & $\mathbf{P}$ & $\mathbf{P}$ & $\mathbf{P}$ & Total \\
& $\mathbf{1}$ & $\mathbf{2}$ & $\mathbf{3}$ & $\mathbf{4}$ & $\mathbf{5}$ & $\mathbf{6}$ & $\mathbf{7}$ & $\mathbf{8}$ & \\
\hline Gerak & 1 & 1 & & 1 & 2 & 1 & 3 & 3 & $\mathbf{1 2}$ \\
\hline Penglihatan & 1 & & 1 & 1 & 2 & 1 & 2 & 1 & $\mathbf{9}$ \\
\hline Pendengaran & & 1 & 1 & & 1 & & & & $\mathbf{3}$ \\
\hline Pengecapan & & & & & & & 1 & & $\mathbf{1}$ \\
\hline Jumlah & & & & & & & & & $\mathbf{2 5}$ \\
\hline
\end{tabular}




\section{Puisi Perjamuan Khong Guan}

Berkerudung langit biru, ibu yang hatinya kokoh membelah dan memotong- motong bulan dan memberikannya kepada anak-anaknya yang ngowoh (C19)

Pada penggalan puisi tersebut terdapat citraan gerak yang ditampilkan oleh penyair. Citraan gerak ditandai dengan kata membelah, dan memotongmotong. Kata tersebut memperlihatkan kepada pembaca adanya gerakan yang dilakukan oleh tokoh Ibu dalam puisi tersebut. Penyair berupaya mengajak pembaca melihat gerakan tokoh ibu dalam puisi tersebut lewat citraan gerak.

Citraan dalam kumpulan puisi Perjamuan Khong Guan dimaksudkan untuk memberikan gambaran yang dapat ditangkap oleh indra manusia. Citraan juga digunakan sebagai pemantik daya bayang atau imajinasi pembaca, sehingga seakan-akan dapat melihat, mendengar ataupun merasakan apa yang diungkapkan oleh penyair (Al-Ma'ruf \& Nugrahani, 2017). Citraan dalam puisi merupakan komponen penting yang dapat membuat karya sastra puisi tersebut telihat lebih indah dan lebih hidup.

Temuan tersebut sejalan dengan hasil penelitian Fajira (2021) mengenai kajian citraan dalam puisi Pesan karangan Soek Hok Gie bahwa citraan dalam sebuah karya sastra puisi memiliki peran untuk memberikan kesan keindahan lewat pengindraan pembacanya. Pada penelitian tersebut juga ditemukan bahwa citraan dalam sebuah karya sastra puisi dipengaruhi oleh hasil pengalaman indra penyairnya. Pada penelitian Fajira citraan yang mendominasi yaitu citraan penglihatan. Citraan tersebut memberikan efek seolah-olah pembaca melihat apa yang digambarkan penyair. Sedangkan pada penelitian ini citraan yang paling dominan yaitu citraan gerak yang difungsikan untuk membangkitkan daya imajinasi pembaca lewat citraan gerak.

Citraan dalam kumpulan puisi Perjamuan Khong Guan digunakan untuk melukiskan objek yang mampu menimbulkan tanggapan respon yang dapat dirasakan oleh pancaindra manusia melalui kata-kata kiasan. Menurut Ratna (2017) citraan dalam puisi digunakan untuk memberikan efek pada indra yang dimiliki manusia pada saat membaca karya sastra puisi. Penggambaran yang cukup jelas membuat pembaca seakan-akan ikut menyaksikan suasana yang hendak Joko Pinurbo gambarkan lewat citraan tersebut.

Sejalan dengan teori Al-Ma'ruf \& Nugrahani (2017) yang berpendapat bahwa citraan merupakan gambaran angan-angan dalam sebuah karya sastra. Temuan tersebut juga relevan dengan penelitian Sujoko (2020) dengan mengenai citraan di kumpulan puisi Syahadat Senggama karangan Asro Al Murthawi. Hasil penelitian tersebut menyimpulkan bahwa citraan

BASASTRA Jurnal Bahasa, Sastra, dan Pengajarannya

Volume 9 Nomor 2, Oktober 2021, P-ISSN 2302-6405, E-ISSN 2714-9765 
dalam puisi digunakan untuk memberikan efek pada indra yang dimiliki manusia pada saat membaca puisi tersebut.

\section{Relevansinya Sebagai Bahan Ajar Bahasa Indonesia}

Penggunaan bahan ajar di sekolah perlu memperhatikan beberapa kriteria bahan ajar. Menurut Rohmansyah (2016) kriteria bahan ajar yang baik harus sesuai dengan (1) kurikulum, (2) tujuan pendidikan, (3) perkembangan kognitif peserta didik, dan (4) relevan dengan perkembangan ilmu dan teknologi. Bahan ajar dari kumpulan puisi ini juga relevan dengan kompetensi dasar yang harus dikuasai oleh siswa.

Penelitian memfokuskan pada KD 3.16, 4.14 dan KD 3.17, 4.17 tentang materi teks puisi kelas X SMA. Materi terdiri dari unsur pembangun puisi. Seperti, diksi, gaya bahasa, citraan, rima, tema dan amanat. Pada kumpulan puisi Perjamuan Khong Guan dari segi isi sangat mewadahi sebagai bahan materi ajar Bahasa Indonesia khususnya pada materi unsur kebahasaan teks puisi. Hasil ini diperoleh melalui ulasan dari informan berupa guru Bahasa Indonesia SMA.

Bahan ajar berupa modul dari kumpulan puisi Perjamuan Khong Guan menggunakan bahasa yang sederhana dan mudah dipahami. Serta tidak mengandung unsur SARA. Sedangkan dari segi kelayakan penyajian bahan ajar sudah memenuhi kriteria yang ditetapkan oleh Depdiknas (2008) terkait pedoman memilih dan menyusun bahan ajar. Pengaplikasian bahan ajar tersebut dapat dilakukan dari tahap menganalisis unsur pembangun puisi hingga pada tahap menulis puisi.

Guru dapat menggunakan hasil penelitian stilistika dari kumpulan puisi Perjamuan Khong Guan sebagai referensi bahan ajar Bahasa Indonesia khususnya pada materi teks menulis puisi. Hasil analisis kumpulan puisi ini sesuai dengan tujuan pembelajaran jika dijadikan sebagai bahan ajar sastra di sekolah.

Selain dapat digunakan sebagai bahan ajar sastra di sekolah. Hasil dari penelitian ini juga dapat dimanfaatkan untuk meningkatkan budaya literasi bagi siswa. Kegiatan literasi di sekolah dapat dilakukan dengan cara membaca dan memahami hasil penelitian. Bermodalkan hasil penelitian stilistika sastra dari kumpulan puisi ini guru dapat secara aktif terlibat dalam pelaksanaan program literasi sekolah terkait kebahasaan dan kesastraan di sekolah.

Bersama dengan arahan guru peserta didik dapat menikmati dan memanfaatkan karya sastra pada kumpulan puisi Perjamuan Khong Guan untuk memperluas wawasan, memperhalus budi pekerti. Peserta didik juga akan mendapatkan pemahaman yang lebih mendalam terkait makna dan nilai-nilai moral dalam kumpulan puisi Perjamuan 
Khong Guan karya Joko Pinurbno. Serta dapat menghargai dan membanggakan sastra Indonesia sebagai khazanah budaya dan intelektual manusia Indonesia.

\section{SIMPULAN}

Berdasarkan hasil penelitian dan pembahasan dapat disimpulkan sebagai berikut (1) kumpulan puisi Perjamuan Khong Guan didominasi dengan penggunaan kata konotatif. Diksi pada kumpulan puisi Perjamuan Khong Guan digunakan untuk menambah kesan estetik dan pemakaiannya disesuaikan dengan tema serta makna yang akan disampaikan oleh penyair. (2) Gaya bahasa dalam kumpulan puisi Perjamuan Khong Guan didominasi oleh penggunaan gaya bahasa metafora. Gaya bahasa dalam kumpulan puisi ini digunakan untuk memperjelas makna dan maksud penyair serta memberikan kesan keindahan. (3) Citraan pada dalam kumpulan puisi Perjamuan Khong Guan didominasi oleh citraan gerak. Citraan gerak dalam puisi tersebut dimaksudkan untuk menggambarkan sesuatu yang tidak bergerak menjadi seolah-olah bergerak ataupun gambaran gerak pada umumnya sehingga pembaca seolah-olah dapat melihat aktivitas yang dilukiskan oleh penyair. (4) Kumpulan puisi Perjamuan Khong Guan karya Joko Pinurbo dapat digunakan dan dikembangkan sebagai bahan ajar Bahasa Indonesia Kelas X SMA khususnya pada KD 3.16, 3.17 dan KD.3.16, 4.17. Selain itu kumpulan puisi Perjamuan Khong Guan juga dapat digunakan untuk pengembangan kemampuan menyimak sastra, membaca sastra, hingga pada tahap menulis sastra.

Hasil penelitian berupa kajian diksi, gaya bahasa dan citraan dalam penelitian ini dapat menambah pemahaman tentang makna dan pesan yang terkandung dalam kumpulan puisi Perjamuan Khong Guan karya Joko Pinurbo. Hasil penelitian dapat menambah wawasan kosakata pembaca lewat diksi konotatif dan diksi lain yang ditemukan dalam penelitian. Temuan diksi, gaya bahasa dan citraan dalam penelitian juga dapat dijadikan sebagai inspirasi untuk menulis puisi dengan nilai estetis yang tinggi. Unsur kebahasaan yang ada dalam kumpulan puisi Perjamuan Khong Guan dapat digunakan sebagai acuan untuk menciptakan karya sastra secara mandiri dan terampil.

\section{REFERENSI}

Al-Ma'ruf, Ali Imron, \& Farida Nugrahani. (2017). Pengkajian Sastra Teori Dan Aplikasi. Surakarta: CV. Djiwa Amarta Press.

Dhanawaty, Ni Made. (2017). Perlunya Penyerapan Unsur Sapaan Kekerabatan Bahasa Daerah Yang Sedang Mengindonesia. Jurnal Tutur: Asosiasi Penelitian Bahasa-bahasa Lokal. Vol 3 (2). 132-140. 
Djafar, Chece. (2020). Kajian Diksi dan Gaya Bahasa Metafora Puisi Ininawa Karya Lakon Sang Kelana Modies Palopo. Jurnal Pendidikan Andi Djema. Vol 3 (2).

Faizun, Mochammad. Analisis Bahasa dalam Puisi Ada Tilgram Tiba Senja Karya W.S Rendra : Kajian Stilistika. Kredo: Jurnal Ilmiah Bahasa dan Sastra. Vol 2 (1). 67 81.

DOI:

https://doi.org/10.24176/kredo.v $4 \mathrm{i} 1.4658$

Fajira, Era. Fitri Wahyuni Lubis. Wan Muna Marwah. (2021). Analisis Citraan Yang Terdapat Dalam Puisi "Pesan" Karya Soe Hok Cie. Bahterasia: Jurnal Ilmiah Pendidikan Bahasa dan Sastra Indonesia. Vol 2 (1). https://doi.org/10.30596/bahteras ia.v2i1.6568

Fransori, Arinah (2017). Analisis Stilistika Pada Puisi Kepada Peminta-Minta Karya Chairil Anwar. Jurnal Deiksi. Vol. 9 (1). $1-12$

Gasong, Dina. (2019). Apresiasi Sastra Indonesia. Yogyakarta: CV Budi Utama.

Ginting, Lao Septi Sika. Novita Aurora Gurusinga, Resnanda Putri Kamania Manik. Analisisi Diksi dan Makna dalam Puisi "Di Ranjang Surgawi" karya Azizah Nur Fitriana. Jurnal Ilmu Pendidikan Bahasa dan Sastra Indonesia. Vol 2 (1). https://doi.org/10.30596/bahteras ia.v2i1.6570

Keraf, Gorys. (2017). Diksi dan Gaya Bahasa. Jakarta: PT Gramedia Pustaka Utama.
Mahmudah, Mar'atul Dini Lathif. (2020). Analisis Stilistika Dan Nilai Pendidikan Karakter Kumpulan Puisi Perihal Gendis Serta Pemanfaatannya Dalam Pembelajaran Sastra. Basastra: Jurnal Bahasa, Sastra, dan Pengajarannya. Vol. 8 (1). 153167.

Mukhlis, Abdul \& Mulyani Mimi. (2018). Pemanfaatan Aspek Stilistika Dalam Antologi Puisi Melipat Jarak Karya Sapardi Djoko Damono Sebagai Materi Pengayaan Sastra Di SM. Jurnal Penelitian Humaniora, Vol. 19, (1). 54-60.

Mulyono, Budi Dwi. (2018). Model Bahan Ajar Bahasa Dan Sastra Indonesia yang Ideal dan Inovaitf. Jurnal Edukasi Kultur: Bahasa, Sastra dan Budaya. Vol. 5 (1). 1-14.

Nugrahani, Farida. (2014). Metode Penelitian Kualitatif dalam Penelitian Pendidikan Bahasa. Solo: Cakra Books

Nurgiyantoro, Burhan. 2017. Stilistika. Yogyakarta: Gadjah Mada University Press.

Ratna, Nyoman Kutha. (2017). Stilistika: Kajian Puitika Bahasa Sastra dan Budaya. Yogyakarta: Pustaka Pelajar.

Rohmansyah, Khalimi. (2016). Pedoman Pemilihan dan Penyajian Bahan Ajar Mata Pelajaran Bahasa dan Sasra Indonesia. Jurnal Logika. Vol. 16 (2). 59-66

Satori, Djam'an \& Komariah Aan. (2017). Metodologi Penelitian Kualitatif. Bandung: CV Alfabeta. 
Sujoko.\& Nasution, Edy Pranata. (2020). Citraan dalam Kumpulan Puisi Syahadat Senggama karya Asro Al Murthawy. Aksara: Jurnal Ilmiah Pendidikan Bahasa dan Sastra Indonesia. Vol 4 (1).

Sunaryo, Zuriah \& Kusniarti. (2017). Model Adaptasi Nilai Kearifan Lokal dalam Pembelajaran Sastra Berkarakter. Jurnal Sosiohumanika: Jurnal Pendidikan Sains Sosial dan Kemanusiaan. Vol 10 (1). 108116. DOI: https://doi.org/ 10.2121/sosiohumanika.v10i1.8 67

Suryani, Nunuk dan Leo Agung, (2012), Strategi Belajar Mengajar, Yogyakarta: Ombak

Sutejo. (2010). Stilistika Teori, Aplikasi dan Alternatif Pembelajarannya. Pustaka Felicha: Yogyakarta.

Sutopo. 2002. Pengantar Penelitian Kualitatif. Surakarta Universitas Sebelas Maret Press. Tarigan, HG. (2011). Prinsip-prinsip Dasar Sastra. Bandung: Angkasa.

Umami, Sahrul \& Anto Puji. (2020). Gaya Bahasa Perbandingan Pada Kumpulan Puisi Dalam Pembelajaran Sastra di SMA. El Banar: Jurnal Pendidikan dan Pengajaran. Vol 3 (1). 224-25.

Ummul, Khair. (2018). Pembelajaran Bahasa Indonesia dan Sastra (BASASTRA) di SD dan MI. ArRiayah : Jurnal Basastra. Vol 2 (1).82-98.

Waluyo, Herman. J . 2010. Pengkajian dan Apresiasi Puisi. Widya Sari Press Salatiga
Wicaksono, Andri. (2019). Apresiasi Puisi Indonesia. Bandar Lampung: AURA CV. Anugrah Utama Raharja.

Zhang, Zhiqin (2010). The Interpretation of a Novel by Hemingway in Terms of Literary Stylistics. Journal of Language Society and Culture. Vol 30 (1). 1155-160.. 